\title{
Risk Factors for Tuberculosis in the Work Area Community Health Center Sabang, Dampelas District, Donggala Regency
}

\author{
Dedi Mahyudin Syam*(D), Ros Arianty (D), Djunaidil Syukur Sulaeman (D), Indro Subagyo (D) \\ Department of Sanitation, Poltekkes Kemenkes Palu, Palu, Indonesia
}

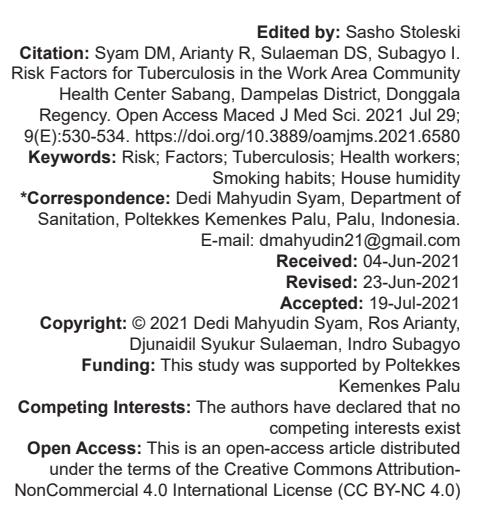

Introduction

Global development has entered a new era. World leaders are committed to ending poverty, promoting the prosperity and well-being of society while protecting the environment by 2030 [1]. Seventeen sustainable development goals (SDGs) were adopted at the United Nations Summit in September 2015. The SDG era began on January 1, 2016, at the same time the new World Health Organization (WHO) End tuberculosis (TB) Strategy to prevent, control and end the TB epidemic came into effect [2]. TB, which is an airborne disease, is a major health problem worldwide. Globally, TB is the second deadliest disease after AIDS [3].

TB is a major health problem in the world. In 20 years, the $\mathrm{WHO}$ and its member countries have been trying to reduce TB. TB is an infectious disease caused by an infectious disease caused by the bacterium Mycobacterium tuberculosis. The source of transmission of smear-positive TB patients is through the droplets of sputum they expel. This disease if not treated immediately or not treated immediately can lead to dangerous complications and even death [4].
TB control and elimination relies on early detection of active TB cases, prompt anti-TB treatment, identification of people at risk of exposure and infection and prevention of secondary TB cases [5]. Specifically, attention given to the factor of poverty, poor living conditions, the various causes of social vulnerability, and reduced access to health services. In addition, there is a need for a better understanding of factors related to behavior (individual and community level) [6]. Based on the 2017 Global TB Report (Kemenkes RI, 2018) in 2016 there were 10,4 million TB incidence cases which is equivalent to 120 cases per 100,000 population. Indonesia ranks second after India in the Southeast Asia region with a TB incidence of $45 \%$. High Burden Countries for TB are based on three indicators, namely, $\mathrm{TB}, \mathrm{TB} / \mathrm{HIV}$, and multidrug-resistant TB. One country can be included in one of these lists or both of them are even included in the three indicators. Indonesia [7].

Based on data from the Central Sulawesi Provincial Health Office $2^{\text {nd }}$ year 2018 TB disease reached 2,674 cases, while the data from the Health Service District Donggala, TB disease in 2018 reached 358 cases [4]. Morbidity of TB Primary Health Centres (PHC) Sabang is still very high, based on the results of 
surveillance reports PHC Sabang In 2013, obtained data on the number of TB patients 13 cases, 29 cases in 2014 , 23 cases in 2015,27 cases of $p$ there is 2016 and the year 2017 the number of people TB 209 suspected TB and 30 cases, TB sufferers in the Sabang Health Center area [8].

Research aims to know the risk factors incidence of TB disease in Sabang Regional Public Health Center, District Dampelas, Donggala.

\section{Materials and Methods}

Analytic research, with a case-control approach carried out from March to May 2019. The case population is all TB patients in the Sabang Public Health Center working area. The sample used was 30 cases and 30 controls, with a ratio of 1:1. Inclusion criteria: TB patients who have been diagnosed by health workers and TB suspects who have an address or reside in the working area of the Sabang Public Health Center, Dampelas District, and are recorded to have received treatment in 20182019 at the Sabang Health Center. Exclusion criteria: patients with TB and TB suspects were aged 5 years and under (toddlers) and is not willing or not able to in the interview.

Data analysis test bivariate use using the Chisquare test with 95\% confidence level, Multivariate testing using regression logistic.

\section{Results}

Overview characteristics respondents Pursuant to sex men more than women are as much as $66.7 \%$, the age group most at the age of $36-40$ years is $30.0 \%$, more education low education levels $66.3 \%$ and livelihoods of respondents most farmers $50.0 \%$, at least as many as $3.3 \%$ civil servants (Table 1 ).

Table 2 shows that the male sex variable is more likely to suffer from TB (33.3\%) than women (16.7\%), TB sufferers who have higher education $(10.0 \%)$. Income level >UMR who suffer from TB (11.7\%) <UMR (38.3\%), good knowledge who suffer from TB $(10.0 \%)$ less than less knowledge (40.0), TB patients who do not smoke $(21.7 \%)$ are less than smoking $(28.3 \%)$, ventilation does not meet the requirements $(35.0 \%)$ patients are greater than not eligible $(15.0 \%)$, TB patients who are densely populated $(31.7 \%)$ are more than not densely populated (18, 3\%), TB sufferers whose homes do not meet the humidity requirements $(31.7 \%)$ more than those who meet the requirements $(18.3 \%)$.
Table 1: The characteristics of the respondents

\begin{tabular}{lll}
\hline Characteristics & $\mathrm{n}$ & $\%$ \\
\hline Gender & & \\
$\quad$ Man & 40 & 66.7 \\
$\quad$ Women & 20 & 33.3 \\
Age Group (Year) & & \\
$20-25$ & 1 & 1.7 \\
$26-30$ & 1 & 1.7 \\
$31-35$ & 11 & 18.3 \\
$36-40$ & 18 & 30.0 \\
$41-45$ & 6 & 10.0 \\
$46-50$ & 14 & 23.3 \\
$51-55$ & 1 & 1.7 \\
$56-60$ & 6 & 10 \\
$61-70$ & 2 & 3.2 \\
Level of education & & \\
High & 22 & 33.7 \\
Low & 38 & 66.3 \\
Type of work & & \\
Civil servants & 2 & 3.3 \\
Farmer & 30 & 50.0 \\
Fisherman & 14 & 23.3 \\
Labor & 7 & 11.7 \\
Traders & 7 & 11.7 \\
Total & 60 & 100 \\
\hline
\end{tabular}

Table 3 show that smoking habit with $p=0.020$ (odds ratio $[O R]=7.120$, confidence interval $[\mathrm{Cl}]=1.358-37.337)$ and house humidity with $\mathrm{p}=0.000$ $(\mathrm{OR}=26.318, \mathrm{Cl}=4.399-157.474)$ were the most dominant risk factors for TB incidence, while the type of gender, education and knowledge are protective against the incidence of TB.

Table 2: Frequency of risk factors with TB patients

\begin{tabular}{|c|c|c|c|c|c|c|}
\hline \multirow[t]{2}{*}{ Variable } & \multirow[t]{2}{*}{$\mathrm{n}$} & \multirow[t]{2}{*}{$\%$} & \multicolumn{4}{|c|}{ TB sufferers } \\
\hline & & & No & $\%$ & Yes & $\%$ \\
\hline \multicolumn{7}{|l|}{ Gender } \\
\hline Male & 40 & 66.7 & 20 & 33.3 & 20 & 33.3 \\
\hline Female & 20 & 33.3 & 10 & 16.7 & 10 & 16.7 \\
\hline \multicolumn{7}{|l|}{ Education } \\
\hline High & 22 & 36.7 & 16 & 26.7 & 6 & 10.0 \\
\hline Low & 38 & 66.3 & 14 & 23.3 & 24 & 40.0 \\
\hline \multicolumn{7}{|l|}{ Income } \\
\hline$>$ UMR & 22 & 36.7 & 15 & 25.0 & 7 & 11.7 \\
\hline$<$ UMR & 38 & 63.3 & 15 & 25.0 & 23 & 38.3 \\
\hline \multicolumn{7}{|l|}{ Knowledge } \\
\hline Good & 32 & 53.3 & 26 & 43.3 & 6 & 10 \\
\hline Less & 28 & 46.7 & 4 & 6.7 & 24 & 40.0 \\
\hline \multicolumn{7}{|l|}{ Smoke } \\
\hline No & 39 & 65.0 & 26 & 43.3 & 13 & 21.7 \\
\hline Yes & 21 & 35.0 & 4 & 6.7 & 17 & 28.3 \\
\hline \multicolumn{7}{|l|}{ Ventilation } \\
\hline No & 26 & 43.3 & 5 & 8.3 & 21 & 35.0 \\
\hline Yes & 34 & 56.7 & 25 & 41.7 & 9 & 15.0 \\
\hline \multicolumn{7}{|c|}{ Occupant Density } \\
\hline No & 35 & 58.3 & 24 & 40.0 & 11 & 18.3 \\
\hline Yes & 25 & 41.7 & 6 & 10.0 & 19 & 31.7 \\
\hline \multicolumn{7}{|l|}{ Humidity } \\
\hline No & 21 & 35.0 & 2 & 3.3 & 19 & 31.7 \\
\hline Yes & 39 & 65.0 & 28 & 46.7 & 11 & 18.3 \\
\hline
\end{tabular}

\section{Discussion}

The TB germ was first discovered by Robert Koch (1882) which later called M. tuberculosis. This germ consists of three variants, namely; Variants Humanus, Bovinus, and Avium. The most common variant found in humans is $M$. tuberculosis humanus. These germs can attack all parts of the human body, and the most frequently attacked are the pulmonary organs (90\%) [9]. Other organs that can also be attacked are the skin (skin TB), bones (bone TB), brain and nerves (bone and nerve TB), and others [10]. 
Table 3: Logistic regression of risk factors with TB patients

\begin{tabular}{|c|c|c|c|c|c|c|c|c|}
\hline \multirow[t]{2}{*}{ Variable } & \multirow[t]{2}{*}{$\mathrm{n}$} & \multirow[t]{2}{*}{$\%$} & \multicolumn{4}{|c|}{ Sufferers } & \multirow[t]{2}{*}{$p$-value } & \multirow[t]{2}{*}{ OR 95\% (Cl) } \\
\hline & & & No & $\%$ & Yes & $\%$ & & \\
\hline \multicolumn{9}{|l|}{ Gender } \\
\hline Male & 40 & 66.7 & 20 & 33.3 & 20 & 33.3 & \multirow[t]{2}{*}{0.076} & \multirow[t]{2}{*}{$0.087(0.092-0.952)$} \\
\hline Female & 20 & 33.3 & 10 & 16.7 & 10 & 16.7 & & \\
\hline \multicolumn{9}{|l|}{ Education } \\
\hline High & 22 & 36.7 & 16 & 26.7 & 6 & 10.0 & \multirow[t]{2}{*}{0.200} & \multirow{2}{*}{$0.187(0.014-2.435)$} \\
\hline Low & 38 & 66.3 & 14 & 23.3 & 24 & 40.0 & & \\
\hline \multicolumn{9}{|l|}{ Knowledge } \\
\hline Good & 32 & 53.3 & 26 & 43.3 & 6 & 10 & \multirow[t]{2}{*}{0.067} & \multirow[t]{2}{*}{$0.074(0.089-0.946)$} \\
\hline Less & 28 & 46.7 & 4 & 6.7 & 24 & 40.0 & & \\
\hline \multicolumn{9}{|l|}{ Smoke } \\
\hline No & 39 & 65.0 & 26 & 43.3 & 13 & 21.7 & \multirow[t]{2}{*}{0.020} & \multirow[t]{2}{*}{$7.120(1.358-37.337)$} \\
\hline Yes & 21 & 35.0 & 4 & 6.7 & 17 & 28.3 & & \\
\hline \multicolumn{9}{|l|}{ Ventilation } \\
\hline No & 26 & 43.3 & 5 & 8.3 & 21 & 35.0 & \multirow[t]{2}{*}{0.874} & \multirow[t]{2}{*}{$1.197(0.130-11.055)$} \\
\hline Yes & 34 & 56.7 & 25 & 41.7 & 9 & 15.0 & & \\
\hline \multicolumn{9}{|c|}{ Occupant Density } \\
\hline No & 35 & 58.3 & 24 & 40.0 & 11 & 18.3 & \multirow[t]{3}{*}{0.549} & \multirow[t]{3}{*}{$1.723(0.291-10.213)$} \\
\hline Yes & 25 & 41.7 & 6 & 10.0 & 19 & 31.7 & & \\
\hline \multicolumn{7}{|l|}{ Humidity } & & \\
\hline No & 21 & 35.0 & 2 & 3.3 & 19 & 31.7 & \multirow[t]{2}{*}{0.000} & \multirow[t]{2}{*}{26.318 (4.399-157.474) } \\
\hline Yes & 39 & 65.0 & 28 & 46.7 & 11 & 18.3 & & \\
\hline
\end{tabular}

The analysis of the education variable shows the results of $p=0.200$, the value $(\mathrm{Cl}=0.014-2.435)$ means that it is not a risk factor for TB. Education is related to patient knowledge. Low patient education results in low knowledge, thus allowing sufferers to drop out of treatment due to the patient's lack of knowledge and inability to understand the treatment. This results in the patient being unable to be regular in the treatment program that is being undertaken. A similar study was conducted in the working area of Community Health Center (Puskesmas) Kertapati Palembang which stated that there was a relationship $(p=0.02)$ between education and the incidence of pulmonary TB [11]. A similar study was conducted in the work area of the Puskesmas Setu, Tangerang, which stated that lack of education could increase 2.05 times the risk of suffering from pulmonary TB compared to those with high education [12].

Ventilation is useful as a place to change air, reduce humidity and the entry of indoor sunlight, besides ventilation can also reduce the number of indoor pulmonary TB germs that are carried by air flow, so as to minimize the possibility of transmitting pulmonary TB to the occupants of the house. In the assessment of a healthy home, the area of ventilation that meets the health requirements is $\geq 10 \%$ of the area of the lighting field [13]. Research conducted in Langsa showed that ventilation had an effect on the incidence of pulmonary TB [14].

A house with a high occupancy density is not healthy, because in addition to causing a lack of oxygen consumption, if one family member has an infectious disease, it will easily be transmitted to other family members. The occupancy density requirements for the entire house are usually expressed in $\mathrm{m}^{2} /$ person. The minimum area per person is very relative depending on the quality of the building and the facilities available. For a simple house minimum extent $8 \mathrm{~m}^{2} /$ person [15], [16], [17], [18]. The rate of transmission of TB in the patient's family environment is quite high, where an average patient can infect 2-3 people in his house. The floor area of a healthy house building must be sufficient for the occupants in it, meaning that the floor area of the house building must be adjusted to the number of occupants so as not to cause overload. People who live in homes with high occupancy rates are at two times more likely to contract TB than people who live in homes with low occupancy rates [19], [20].

Cigarette smoke contains more than 4,500 chemicals that have various toxic, mutagenic, and carcinogenic effects. Cigarette smoke produces a variety of components in both the cellular and extracellular compartments, ranging from water and gas soluble particles. Many substances are carcinogenic and toxic to cells, but tar and nicotine have been shown to be immunosuppressive by affecting the innate immune response of the host and increasing susceptibility to infection. The higher the tar and nicotine levels the effect on the immune system also increases. The risk of TB can be reduced by nearly two-thirds if a person stops smoking [21].

The analysis showed the value of $p=0.002$, means that there is a relationship smoking on the incidence of pulmonary TB Value $(\mathrm{OR}=7.120$, $\mathrm{Cl}=1.358-37.337)$ showed that respondents who have a habit of smoking have a risk of 7.120 times greater than the respondents who do not have the habit smoke. Smoking is a major cause of chronic and obstructive pulmonary diseases, such as bronchitis and emphysema. Smoking is also linked to influenza and other pneumonia. In people with asthma, smoking will worsen asthma symptoms because smoking will further constrict the airways. These detrimental effects include increased susceptibility to chronic cough, sputum production and hoarseness [21].

Smoking is burning tobacco which is then inhaled. Based on the results of Riskesdas, the average number of cigarettes smoked per day per person in Indonesia is 12 cigarettes or the equivalent of one pack. Smoking also increases the risk of pulmonary TB 2.2 times [22].

A study conducted at the Medical University Shuang Ho Hospital in New Taipei (Taiwan) were active smokers had an OR of $1.36(95 \% \mathrm{Cl}=1.03-2.36)$, $p<0.05)$ relative to nonsmokers [23]. The results of the same study conducted in the province of Henan, China that smokers have a risk factor 2,07 times $(\mathrm{OR}=2.07$, 95\% Cl: 1.66-3.19) in an appeal to nonsmokers [3]. Another study conducted in Taiwan showed that smoking increased TB mortality ninefold $(O R=8.56)$, but when they quit smoking, the risk was reduced by more than half $(65 \%)$ [24].

Statistically, humidity is the most dominant risk factor with $p=0.000,(\mathrm{OR}=26,318, \mathrm{Cl}=4.399$ 157.474). People who live in homes with high humidity are 26,318 times more likely to get TB than people who live in homes with low humidity. The bacteria M. tuberculosis as it does other bacteria will thrive in environments with high humidity. Water makes up 
$>80 \%$ of the volume of bacterial cells and is essential for the growth and survival of bacterial cells. Increased humidity is a good medium for pathogenic bacteria including TB.

From the results of research in the area of Tulis Subdistrict, Batang Regency, the humidity level was $p=0.004$, meaning that there was a significant relationship between house humidity and the incidence of pulmonary TB. The result of $\mathrm{OR}=4.792$ houses with high humidity will affect the occupants to be exposed to pulmonary TB as much as 4.792 times compared to houses with low humidity levels [12]. Relative humidity between $31.0 \%$ and $69.0 \%(95.8 \%$ of cases; $p=0.00<0.05)$; In the Brazilian city of Taguatinga, it has an effect on the incidence of TB [25].

Air humidity is one of the factors that cause the growth of bacteria, especially TB bacteria, which can multiply well. Respondents with Positive Pulmonary TB acid-fast bacillus (AFB) living in a house with high humidity also correlated with the incidence of positive pulmonary AFB TB because it is a good medium for the growth and proliferation of TB germs [26]

\section{Conclusion}

Smoking habits and house humidity are the most dominant risk factors for the incidence of TB in the work area of the Sabang Health Center, Dampelas District, Donggala Regency. Health workers should increase education to the public about the dangers of smoking and the requirements of healthy housing.

\section{References}

1. Lönnroth K, Raviglione M. The WHO's new end TB strategy in the post-2015 era of the sustainable development goals. Trans R Soc Trop Med Hyg. 2016;110(3):148-50. https://doi. org/10.1093/trstmh/trv108

\section{PMid:26884490}

2. Dalton T, Cegielski P, Akksilp S, Mph LA, Caoili JC, Cho PS, et al Prevalence of and risk factors for resistance to second-line drugs in people with multidrug-resistant tuberculosis in eight countries : A prospective cohort study. Lancet. 2012;380(9851):1406-17. https://doi.org/10.1016/s0140-6736(12)60734-x

PMid:22938757

3. Zhang C. Determinants of multidrug-resistant tuberculosis in Henan province in China: A case control study. BMC Public Health. 2016;16(1):42. Available from: https://www. scopus.com/inward/record.uri?partnerlD=HzOxMe3b and $\mathrm{scp}=84954456171$ and origin=inward. https://doi.org/10.1186/ s12889-016-2711-z. [Last accessed on 2021 Jun 1].

4. Sulteng DP. Profil Kesehatan Provinsi Sulawesi Tengah 2018; 2019.
5. Lönnroth K, Migliori GB, Abubakar I, Ambrosio LD, de Vries G, Diel R, et al. Towards tuberculosis elimination: An action framework for low-incidence countries. Eur Respir J. 2015;45(4):928-52.

PMid:25792630

6. Liu Y, Jiang S, Liu Y, Wang R, Li X, Yuan Z, et al. Spatial epidemiology and spatial ecology study of worldwide drugresistant tuberculosis. Int J Health Geogr. 2011;10(1):50. https:// doi.org/10.1186/1476-072x-10-50

PMid:21812998

7. World Health Organization. Global Tuberculosis Report 2018. Geneva: World Health Organization; 2018.

8. Donggala District Health Office. Health Profile Report 2017 of Donggala District. Donggala, 2018.

9. Tuberkulosis Paru: Penyebab Kematian Ke-2 Di Indonesia; 2014. Available from: http//wwwtanyadok.com/kesehatan/ tuberkulosis-parupenyebab-kematian-ke-2-di-indonesia. https:// doi.org/10.22435/mpk.v26i4.4822.191-200. [Last accessed on 2021 May 20]

10. Ma HS. Factors affecting the occurrence of pulmonary tb and efforts to overcome. J Ekol Kesehat. 1992;9(4):1340-6.

11. Oktavia S, Mutahar R, Destriatania S. Analysis of risk factors for pulmonary tb incidence in work area health kertapati palembang. J Ilmu Kesehat Masy. 2016;7(2):124-38. https://doi. org/10.26553/jikm.2016.7.2.124-138

12. Indriyani N, Nor Istiqomah MC. Hubungan kelembaban rumah dengan tuberkulosis paru di kecamatan tulis kabupaten batang. Unnes J Public Health. 2016;5(3):214-20. https://doi. org/10.15294/ujph.v5i3.11311

13. RIDK. Pedoman Nasional Penanggulangan Tubercullosis Cetakan Kedua. Jakarta: RIDK; 2011.

14. Muchsin M. The influence of nutritional status and ventilation on the incidence of pulmonary tuberculosis at Langsa. Open Access Maced J Med Sci. 2019;7(20):3421-4. https://doi. org/10.3889/oamjms.2019.436

PMid:32002065

15. Haider BA, Hatcher J. Daily contact with a patient and poor housing affordability as determinants of pulmonary tuberculosis in urban Pakistan Daily contact with a patient and poor housing affordability as determinants of pulmonary tuberculosis in urban Pakistan. Int J Mycobacteriol. 2015;2(1):38-43. https://doi. org/10.1016/j.jjmyco.2012.12.003

PMid:26785787

16. Kirenga BJ, Ssengooba W, Muwonge C, Nakiyingi L, Kyaligonza S, Kasozi S. Tuberculosis risk factors among tuberculosis patients in Kampala, Uganda: Implications for tuberculosis control. BMC Public Health. 2015;15:1-7. https:// doi.org/10.1186/s12889-015-1376-3

17. Corburn J, Hildebrand C. Slum Sanitation and the Socia Determinants of Women's Kenya: Health in Nairobi; 2015. https://doi.org/10.1155/2015/209505

18. Aldridge RW, Zenner D, White PJ, Muzyamba MC Loutet M, Dhavan P, et al. Prevalence of and risk factors for active tuberculosis in migrants screened before entry to the UK: A population-based cross-sectional study. Lancet Infect Dis. 2016;16(8):962-70. https://doi.org/10.1016/ s1473-3099(16)00072-4

PMid:27013215

19. Pulmonary Tuberculosis in Palembang, South Sumatera. Tuberkulosis Paru di Palembang. Vol. 72. Sumatera Selatan: Pulmonary Tuberculosis in Palembang; 2001. https://doi. org/10.21109/kesmas.v5i5.132

20. Budi IS, Ardillah Y, Sari IP. Analisis Faktor Risiko Kejadian penyakit Tuberculosis Bagi Masyarakat Daerah Kumuh Kota Palembang. J Kesehatan Lingkungan Indones. 2018;17:87-94. 
https://doi.org/10.14710/jkli.17.2.87-94

21. Wijaya AA. Merokok dan tubercolosis. J Tubercolosis Indones. 2012;8:18-23.

22. Kementerian Kesehatan RI. Laporan Riset Kesehatan Dasar Tahun 2013. Kementerian Kesehatan. Jakarta: Kementerian Kesehatan Rl; 2013. https://doi.org/10.24252/bio.v5i1.3429

23. Feng $\mathrm{P}$, Chuang $\mathrm{K}$, Bien $\mathrm{M}$. Cigarette smoke is a risk factor for severity and treatment outcome in patients with culture positive tuberculosis. Ther Clin Risk Manag. 2015;11:1539-44. https:// doi.org/10.2147/tcrm.s87218

PMid:26504395

24. Wen C, Chan T, Chan H, Tsai M, Cheng T, Tsai S. The reduction of tuberculosis risks by smoking cessation. BMC Infect Dis. 2010;10:156. https://doi.org/10.1186/1471-2334-10-156 PMid:20529257

25. Monteiro F, Fernandes DC, de Souza E, Melo D, Sampaio A, Nantua S. Relationship between climatic factors and air quality with tuberculosis in the federal district. Braz J Infect Dis. 2017;21(4):369-75.

PMid:28545939

26. Aditama W, Sitepu FY, Saputra R. Relationship between Physical Condition of House Environment and the Incidence of Pulmonary Tuberculosis, Aceh, Indonesia. Aceh, Indonesia According to Law of the Republic; 2019. 